\title{
Different Origins of the Fractionation of Platinum-Group Elements in Raobazhai and Bixiling Mafic-Ultramafic Rocks from the Dabie Orogen, Central China
}

\author{
Qing Liu, ${ }^{1}$ Quanlin Hou, ${ }^{1}$ Liewen Xie, ${ }^{2}$ Hui Li, ${ }^{3}$ Shanqin $\mathrm{Ni}^{4}{ }^{4}$ and Yudong $\mathrm{Wu}^{4}$ \\ ${ }^{1}$ Key Laboratory of Computational Geodynamics, Graduate University of Chinese Academy of Sciences, \\ Chinese Academy of Sciences, 19 Yuquan Road, Beijing 100049, China \\ ${ }^{2}$ State Key Laboratory of Lithospheric Evolution, Institute of Geology and Geophysics, Chinese Academy of Sciences, \\ P.O. Box 9825, Beijing 10029, China \\ ${ }^{3} 416$ Geological Prospecting Party, Bureau of Geology, Mineral Exploration and Development, Hunan Province, \\ Zhuzhou 412007, China \\ ${ }^{4}$ Institute of Mineral Resources, Chinese Academy of Geological Sciences, 26 Baiwanzhuang Road, Beijing 100037, China
}

Correspondence should be addressed to Qing Liu, 790908619@qq.com

Received 13 January 2012; Accepted 11 May 2012

Academic Editor: Yi-Wen Ju

Copyright () 2012 Qing Liu et al. This is an open access article distributed under the Creative Commons Attribution License, which permits unrestricted use, distribution, and reproduction in any medium, provided the original work is properly cited.

\begin{abstract}
Concentrations of the platinum group elements (PGEs), including $\mathrm{Ir}, \mathrm{Ru}, \mathrm{Rh}, \mathrm{Pt}$, and Pd, have been determined for both Raobazhai and Bixiling mafic-ultramafic rocks from the Dabie Orogen by fire assay method. Geochemical compositions suggest that the Raobazhai mafic-ultramafic rocks represent mantle residues after variable degrees of partial melting. They show consistent PGE patterns, in which the IPGEs (i.e., Ir and Ru) are strongly enriched over the PPGEs (i.e., Pt and Pd). Both REE and PGE data of the Raobazhai mafic-ultramafic rocks suggest that they have interacted with slab-derived melts during subduction and/or exhumation. The Bixiling ultramafic rocks were produced through fractional crystallization and cumulation from magmas, which led to the fractionated PGE patterns. During fractional crystallization, Pd is in nonsulfide phases, whereas both Ir and Ru must be compatible in some mantle phases. We suggest that the PGE budgets of the ultramafic rocks could be fractionated by interaction with slab-derived melts and fractional crystallization processes.
\end{abstract}

\section{Introduction}

The platinum group elements (PGEs), including Os, Ir, Ru, $\mathrm{Rh}, \mathrm{Pt}$, and $\mathrm{Pd}$, are strongly siderophile and chalcophile elements. They have similar geochemical behaviors during magmatic processes. Traditionally, the PGEs are subdivided into two groups, the compatible IPGEs ( $\mathrm{Os}$, Ir, and $\mathrm{Ru}$ ) and the incompatible PPGEs ( $\mathrm{Rh}, \mathrm{Pd}$, and $\mathrm{Pt}$ ) [1]. It has been suggested that the IPGEs are refractory and tend to be retained in the mantle peridotites during partial melting [2]. In contrast, the PPGEs are concentrated in the base metal sulphides (e.g., pentlandite, chalcopyrite), which are released to the melts along with the molten sulfide melts [2]. Because of their unique geochemical characteristics, the PGEs can be used to identify the magma sources and unravel the complex petrogenetic processes, such as partial melting, melt percolation, and metasomatism in the mantle [1]. Mafic-ultramafic rocks have lower REE contents but higher PGE contents than other rocks, so the PGEs have advantages in studying their petrogenetic processes $[1,3-7]$.

In this study, we present the PGE data of both Raobazhai and Bixiling mafic-ultramafic rocks from Dabie Orogen, central China, to discuss their fractionation behaviours during magma evolution. The mechanisms of differentiation between these elements will be examined below, taking into account the geochemical affinities of the PGE and their partition in the mineral phases. The results also demonstrate that the PGEs can provide important information on the genesis of magmas. 


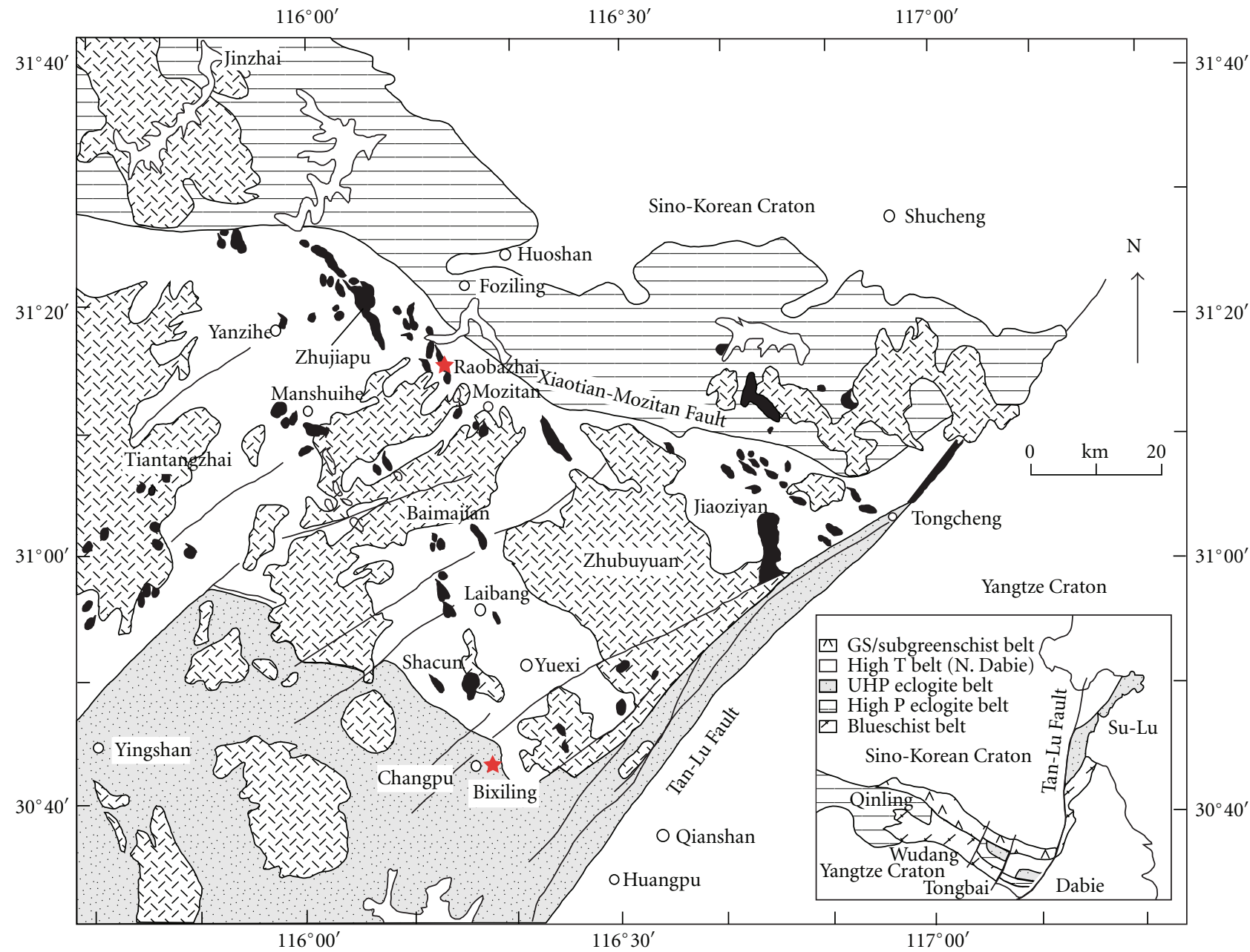

娄 Cretaceous granites $\square$ N. huaiyang belt
Mafic-ultramafic rocks $\square$ Dabie UHP terrane
$\square$ Granitic gneisses

Figure 1: Simplified geological map of the Dabie Complex [8]. Sampling localities are roughly indicated by the names of Raobazhai and Bixiling.

\section{Geological Background and Occurrence}

The Dabie Orogen is the eastern segment of the QinlingDabie Orogen, which was formed by the continental collision between the Yangtze Craton and North China Craton (Figure 1). It has been subdivided, from north to south, into five main tectonic zones by several large-scale EW-trending faults $[8,10,11]$.

The Raobazhai ultramafic massif is outcropped in the North Dabie high-temperature and ultra-high-pressure (HT/UHP) granulite-facies zone. It is located at ca $5 \mathrm{~km}$ south of the Xiaotian-Mozitan Fault (Figure 1), which is a major strike-slip fault along the eastern part of the QinlingTongbai-Dabie orogenic belt that might have witnessed the early evolutions of this orogenic belt [13]. Previous studies have suggested that the Raobazhai massif is a sheet-like peridotitic slice, which is in fault contact with the surrounding amphibolite facies orthogneisses [14-16]. Migmatization can be locally observed in field. The long dimension of the massif is subparallel to the strike of the Xiaotian-Mozitan Fault and the regional foliation. The Raobazhai ultramafic body mainly consists of spinel harzburgites, with minor dunites and lherzolites [16]. They are all highly deformed and metamorphosed. Previous petrographic, geochemical, and thermobarometric studies have suggested that they represent a tectonic slice of the subcontinental lithospheric mantle [16-18]. Five representative samples have been selected in this study.

The Bixiling Complex is the largest $\left(\sim 1.5 \mathrm{~km}^{2}\right)$ coesitebearing mafic-ultramafic body in the Dabie Orogen, which occurs as a tectonic block that is enclosed within the foliated quartzofeldspathic gneisses in the eastern part of the Dabie UHP terrane (Figure 1). It consists predominantly of banded 
eclogites and about 20 elongated lenses of garnet-bearing ultramafic rocks, for example, garnet peridotites, garnet pyroxenites, and wehrlites, which range from 50 to $300 \mathrm{~m}$ in length and from 5 to $50 \mathrm{~m}$ in width [19]. The contact between eclogite and ultramafic rocks is gradational. Field relationships and petrological evidence indicate a cumulate origin of the mafic-ultramafic rocks [19]. Therefore, the diverse rock types are considered, at least to a first approximation, as magmatically cogenetic [20]. The selected samples include three nattier blue eclogites (garnet, omphacite, kyanite, phengite, and rutile), two greenish black eclogites (garnet, omphacite, rutile, and quartz), and two garnet peridotites (olivine, orthopyroxene, clinopyroxene and garnet).

\section{Materials and Methods}

Samples were ground to 200 mesh powders using an agate mill. Whole-rock major elements were determined by X-ray fluorescence spectrometry (XRF) using a Phillips PW 2400 sequential XRF instrument at the Institute of Geology and Geophysics, Chinese Academy of Sciences (IGGCAS). The analytical precision is better than $\pm 2 \%$ for major oxides. Bulk-rock rare earth elements (REE) were analyzed on the Plasma PQ2 inductively coupled plasma mass spectrometry (ICP-MS) at IGGCAS. Replicate analyses of a monitor sample suggest that the reproducibility for the REE analysis is better than 3.5\%.

Whole-rock PGE contents were analyzed by fire assay (FA) method and measured on a Plasma PQ2 ICP-MS at IGGCAS. About $15 \mathrm{~g}$ sample powder, together with $20 \mathrm{~g}$ $\mathrm{Na}_{2} \mathrm{~B}_{4} \mathrm{O}_{7}, 10 \mathrm{~g} \mathrm{Na}_{2} \mathrm{CO}_{3}, 2 \mathrm{~g} \mathrm{Ni}, 2 \mathrm{~g} \mathrm{~S}$, and some $\mathrm{SiO}_{2}$, was fused in a fire-clay crucible at $1150^{\circ} \mathrm{C}$ for 2 hours. Then, the crucible was broken and a sulphide bead was recovered. The bead was dissolved in a Teflon beaker using $15 \mathrm{~mL}$ $\mathrm{HCl}$. After the bead disintegrated into powder, $2 \mathrm{~mL}$ Te and $4 \mathrm{~mL} \mathrm{SnCl}_{2}$ were added into the solution. The solution was heated to become clear and then was filtered to collect the insoluble residue. The residue was cleaned and transferred into a Teflon beaker containing $2.5 \mathrm{~mL}$ aqua regia. Once the solution became clear, appropriate amounts of Re and Cd spike solutions were then added to the mixture, which was diluted with $50 \mathrm{~mL} \mathrm{H}_{2} \mathrm{O}$ for TJA Pro Excel inductively coupled plasma mass spectrometry (ICP-MS) determination. The detection limits, which are defined as average blank plus three standard deviations, for $\mathrm{Ir}, \mathrm{Ru}, \mathrm{Rh}, \mathrm{Pt}$ and $\mathrm{Pd}$ were $0.002,0.0086,0.0048,0.082$, and $0.043 \mathrm{ppb}$, respectively. The PGE contents of most samples are higher than the detection limits, whereas both Ir and Ru contents of some samples are close to their detection limits. Replicate analyses of standard WPR-1 have respectively given values of $13.6 \mathrm{ppb} \mathrm{Ir}, 9.7 \mathrm{ppb}$ $\mathrm{Ru}, 13.7 \mathrm{ppb} \mathrm{Rh}, 257 \mathrm{ppb} \mathrm{Pt}$ and $248 \mathrm{ppb} \mathrm{Pd}$. The average element concentrations of replicate analyses of WPR-1 are within $10 \%$ of the certified value except Ir which is $13 \%$ lower.

\section{Results}

4.1. Raobazhai Mafic-Ultramafic Rocks. The major-, traceelements and PGE concentration data of the Raobazhai

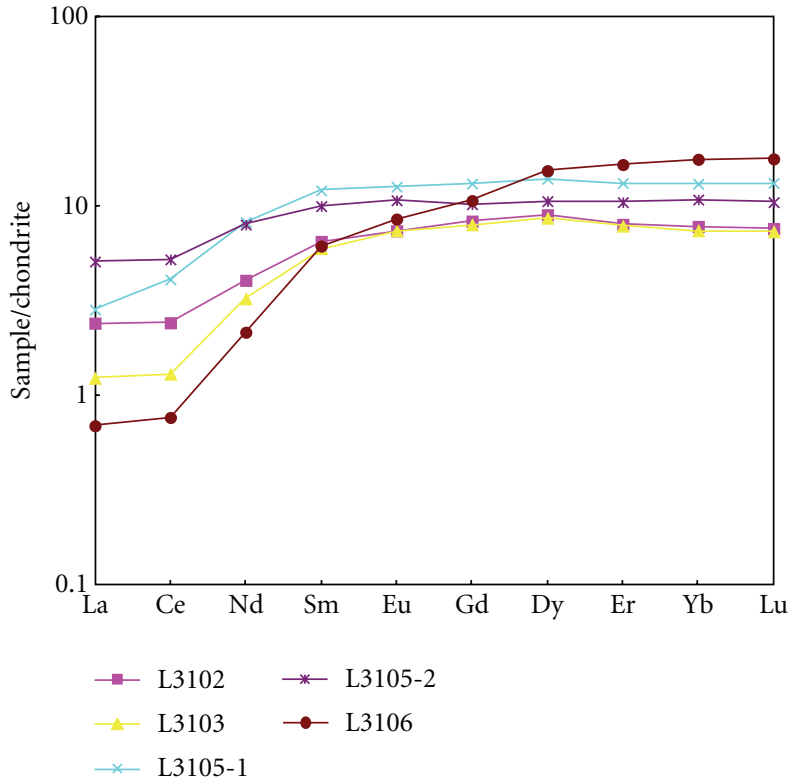

(a)

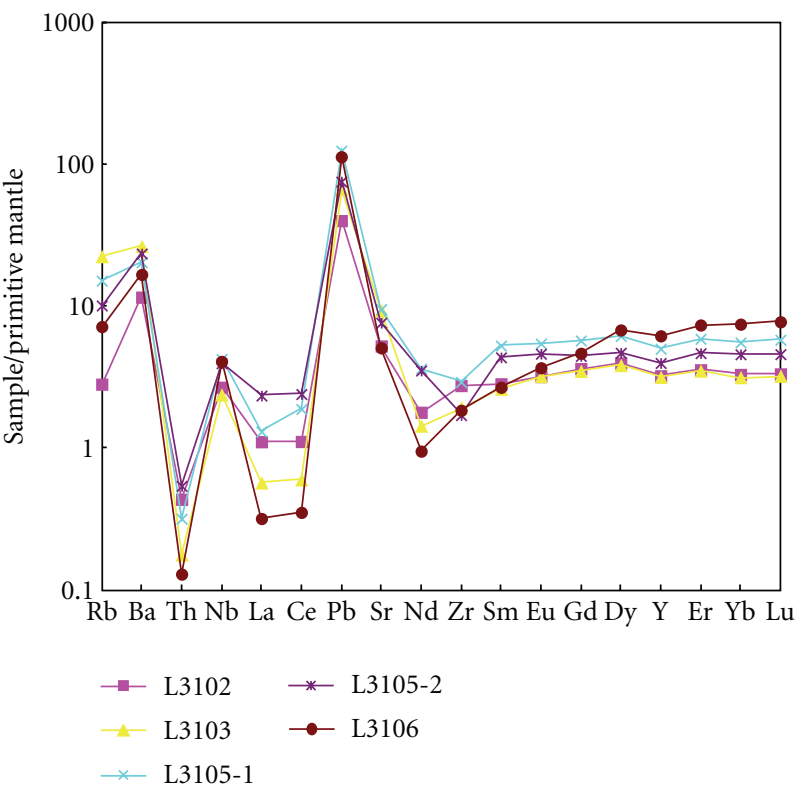

(b)

FIgure 2: Chondrite-normalized REE patterns (a) and spider patterns (b) of Raobazhai mafic-ultramafic rocks (chondrite and primitive mantle values are from [9]).

mafic-ultramafic rocks are given in Table 1. The Raobazhai samples show consistent REE patterns (Figure 2(a)), that is, flat HREE patterns but variable depletion in LREE. Similar results have been reported in a previous study on the Raobazhai peridotites [9]. The REE are incompatible elements during partial melting of mantle peridotites; removal of basaltic components tend to decrease the REE contents of the mantle peridotites. In comparison, the LREE are more incompatible within mantle minerals than the HREE; therefore, the residual peridotites are depleted in LREE 


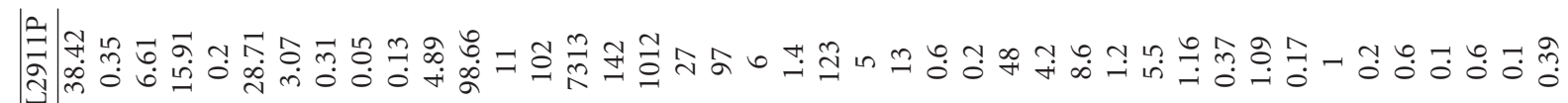
氙 ज

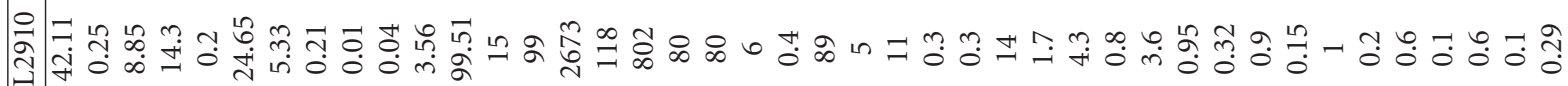
$\frac{2}{0}$

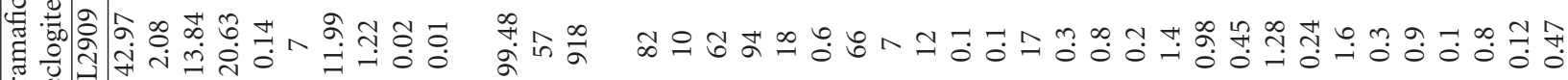

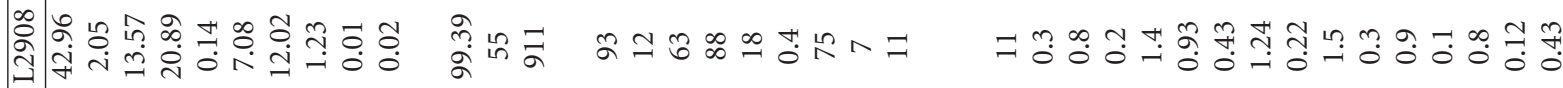

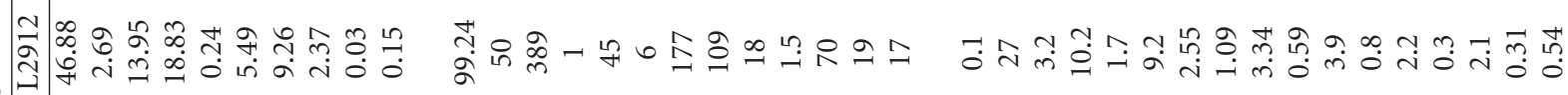

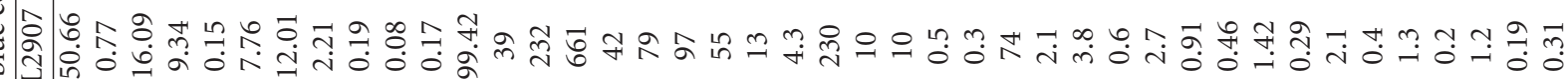

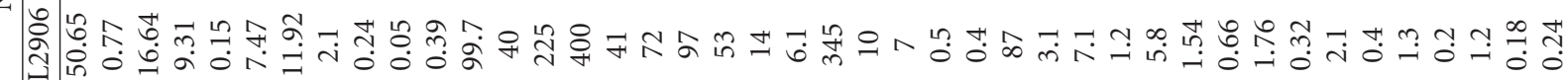

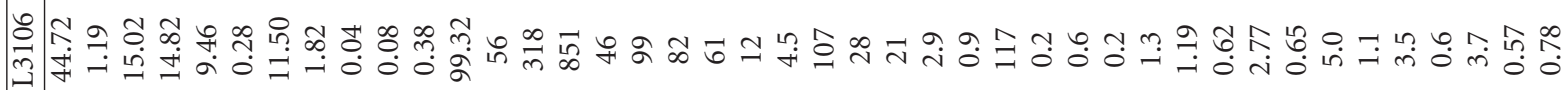

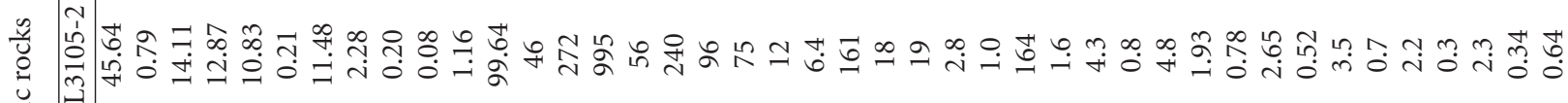

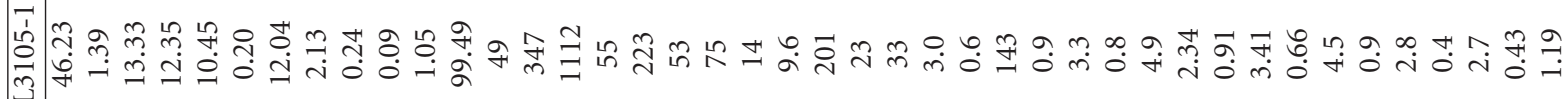

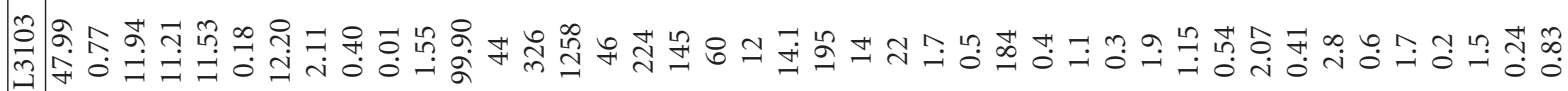

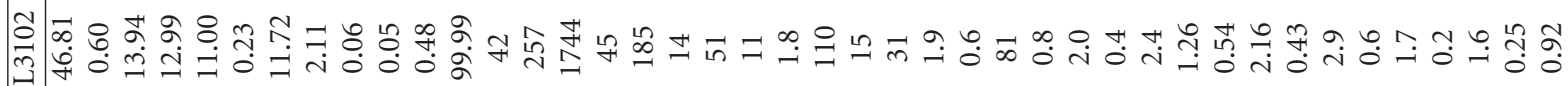




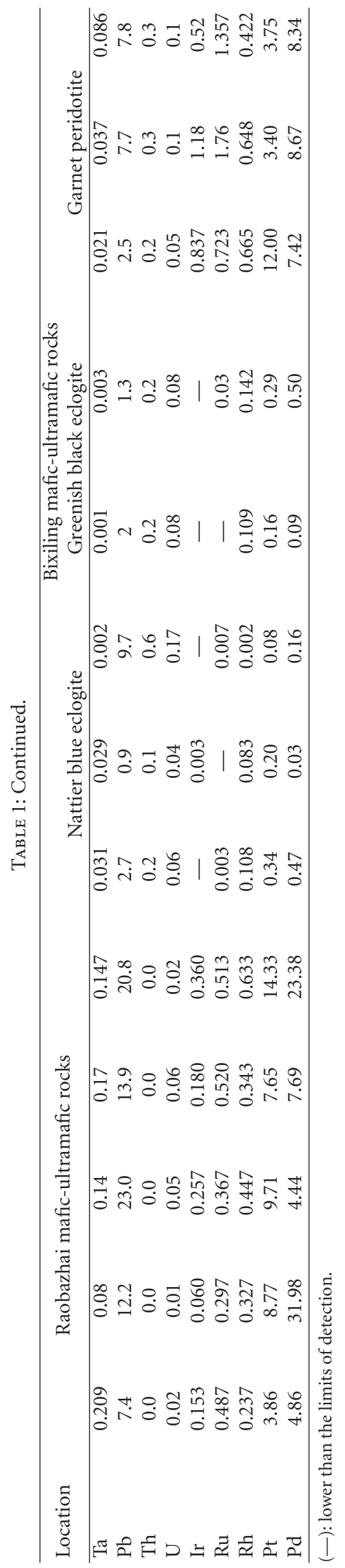




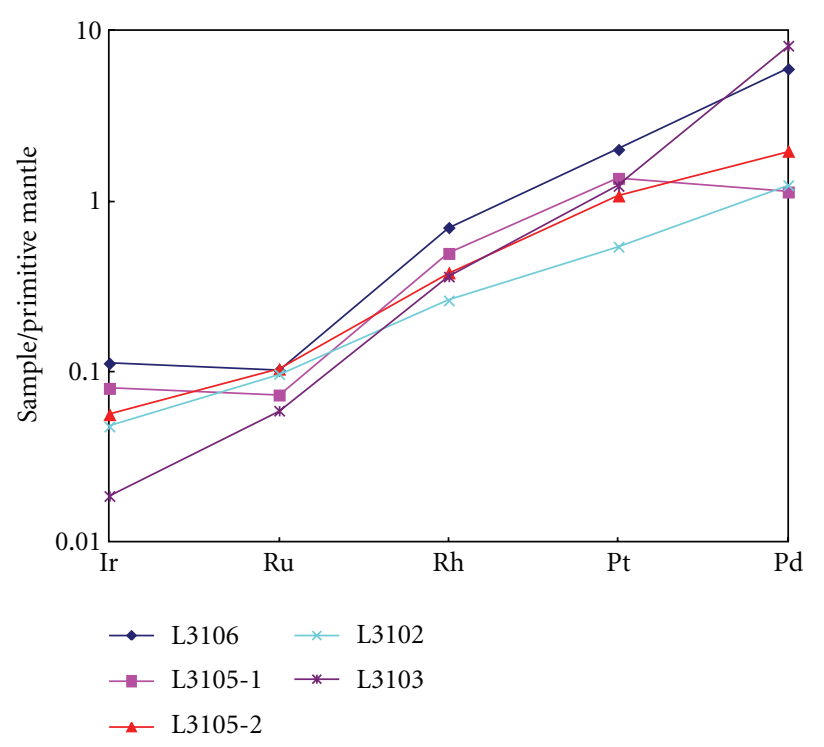

Figure 3: Primitive mantle-normalized PGE abundances for the Raobazhai mafic-ultramafic rocks (Normalizing values are after $[1])$.

relative to the HREE [21]. The Raobazhai peridotites are ubiquitously depleted in LREE, which suggest that they represent mantle residues after variable degrees of partial melting. In the (primitive mantle)-PM-normalized trace element diagram (Figure 2(b)), most Raobazhai samples show variable enrichment in LILE (e.g., Sr, Ba, and $\mathrm{Rb}$ ). In particular, both $\mathrm{Rb}$ and $\mathrm{Ba}$ have concentrations ten times higher than those of the primitive mantle. The enrichment of LILE is an important feature of the Raobazhai mafic-ultramafic rocks. It has been suggested that enrichment of $\mathrm{Rb}$ and $\mathrm{Ba}$ in mantle peridotites could result from subduction-related metasomatism [21]. Zhi et al. [18] also concluded that the enrichment of LILE shown by the Raobazhai ultramafic rocks might be probably related to the slab-released fluids.

The total PGE contents of the Raobazhai mafic-ultramafic rocks range from 9.6 to $41.4 \mathrm{ppb}$, with an average of $24.4 \mathrm{ppb}$, which are higher than the estimated values of the primitive mantle (20.1 ppb) but similar to the Alpine-type orogenic peridotites, for example, Ronda (17.5-39.5 ppb) and the Beni Bousera (17.2-32.5 ppb) [22]. All Raobazhai mafic-ultramafic rocks display consistent and pronounced positive PGE patterns (Figure 3); they are strongly enriched in PPGEs (e.g., Pt and Pd) over IPGEs (e.g., Ir and Ru). Their Pd/Ir ratios vary from 17 to 65 . Both Ir and Ru show good positive correlations with $\mathrm{Ni}$, which suggest they behave as compatible elements during partial melting [23, 24]. In contrast, both Pt and Pd behave as incompatible elements. Therefore, the concentrations of Ir and $\mathrm{Ru}$ increase in the residual peridotites along with the melt extraction, whereas melts are enriched in both $\mathrm{Pd}$ and $\mathrm{Pt}$ relative to $\mathrm{Ir}$ and $\mathrm{Ru}$. This suggests that the residual mantle peridotites should enrich in IPGEs over PPGEs, which is in contrast to the PGEs patterns shown by the Raobazhai mafic-ultramafic rocks. Therefore, the PGE budgets of the Raobazhai peridotites have been affected by processes other than partial melting.

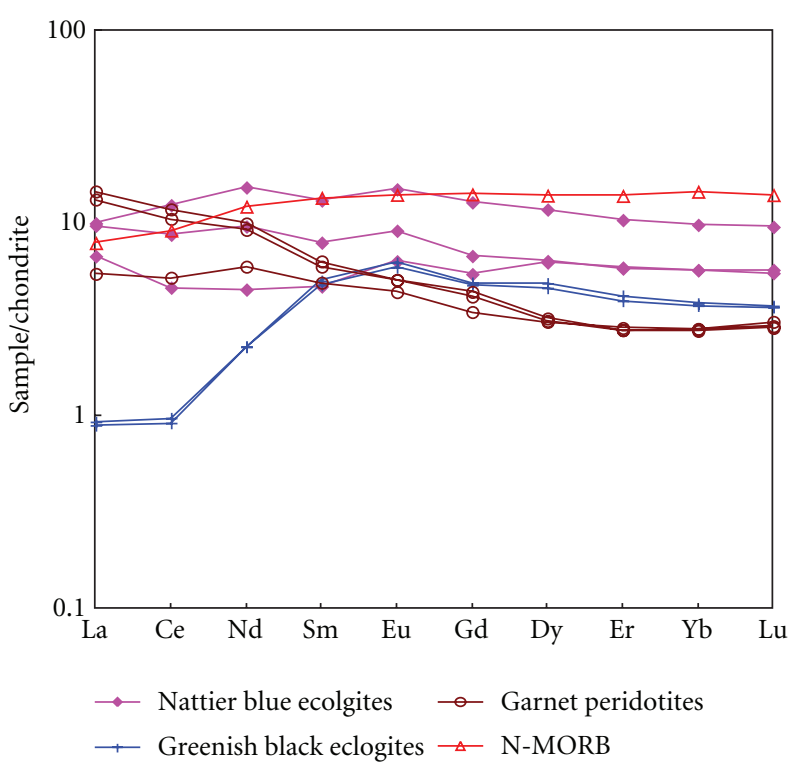

(a)

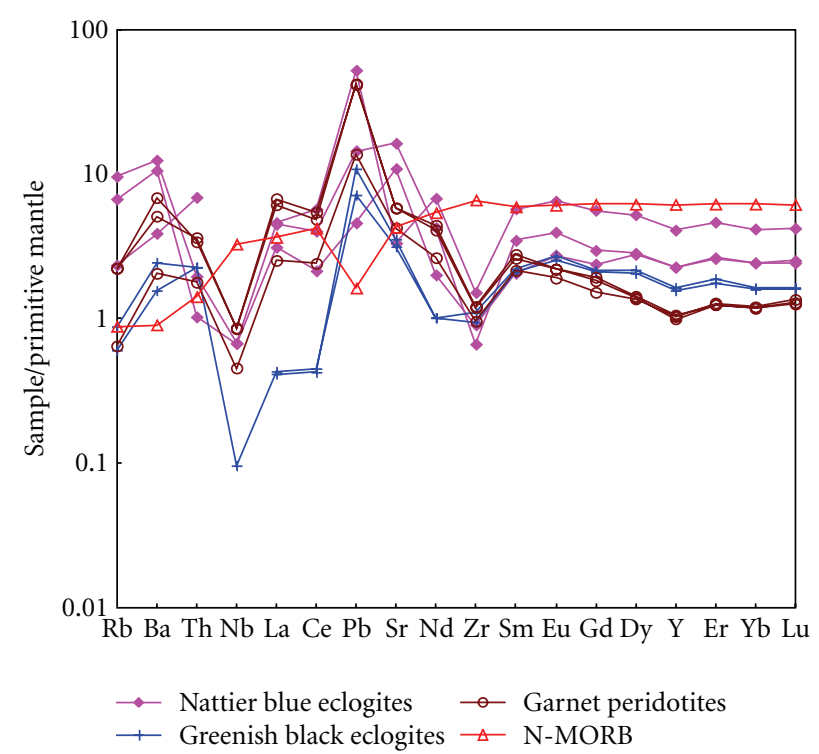

(b)

FIGURE 4: Chondrite-normalized REE patterns (a) and spider patterns (b) of Bixiling mafic-ultramafic rocks (Chondrite, Primitive mantle, and N-MORB values are from [9]).

4.2. Bixiling Eclogites and Peridotites. Both REE and PGE data for five eclogites and two garnet peridotites from Bixiling are given in Table 1, and their distribution patterns are shown in Figures 4 and 5. All eclogites show remarkable positive Eu anomalies, suggesting that they were originally transformed from rocks with cumulated plagioclase. Three nattier blue eclogites selected in this study have quiet similar REE patterns with variable enrichment in LREE (Figure 4(a)), which are consistent with results reported in a previous study [20]. Compared to the normal mid-ocean ridge basalts (N-MORB), the Bixiling nattierblue eclogites have relatively low HREE contents and are slightly enriched in LREE. 


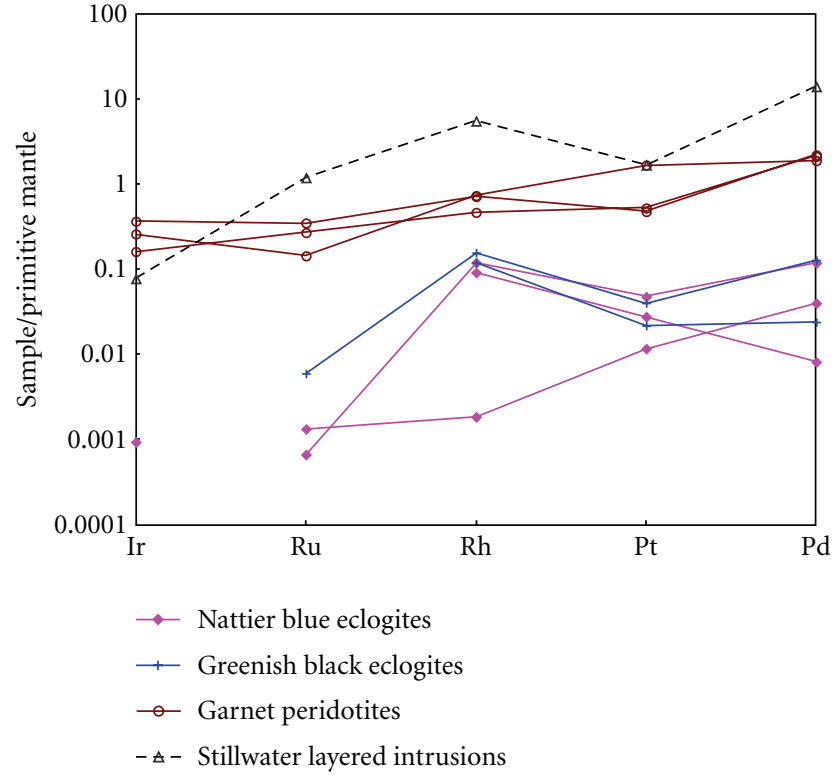

Figure 5: Primitive mantle-normalized PGE abundances for the Bixiling mafic-ultramafic rocks (Normalizing values are after [1]).

This suggests that they were not originally metamorphosed from N-MORB [20]. In contrast, the greenish black eclogites have lower REE contents and are strongly depleted in LREE (Figure 4(a)). This may be because the LREEs are incompatible in olivine, pyroxene, and garnet, but rich in liquid phase during the differentiation process, which make cumulation conglomerate facies that were formed by fractional crystallization have a relative depletion in LREE, and their HREE abundance also different from N-MORB. Compared to the eclogites, the garnet peridotites have lower HREE contents. They are variably enriched in LREE, which are also differed from both garnet peridotites entrained in kimberlites and Alpine-type orogenic peridotites [25]. The patterns suggest that these two garnet peridotites represent a more advanced crystal cumulation [20]. In the trace-element diagram (Figure 4(b)), both garnet peridotites and eclogites show pronounced negative $\mathrm{Zr}$ and $\mathrm{Nb}$ anomalies. Depletion of $\mathrm{Zr}$ has been suggested to be an indigenous feature of the upper mantle origin. The negative $\mathrm{Nb}$ anomaly is an important fingerprint of subduction-related magmas and continental crust. Based on Sr-Nd isotopes of the Bixiling eclogites and garnet peridotites, Chavagnac and Jahn [20] suggested that the Bixiling magmas were contaminated, probably by lower-crustal granulites that are depleted in LILE. The contamination did not significantly modify the Sr isotops, but could result in lowering in $\varepsilon N d$ values and negative $\mathrm{Nb}$ anomaly as observed [20]. A previous study on oxygen isotopic compositions of silicate minerals in the Bixiling eclogites and garnet peridotites has suggested that the original magmas were derived from the upper mantle but probably contaminated by small amounts of crustal rocks during their differentiation processes [26].

The Bixiling mafic-ultramafic rocks display PGE patterns increasing from IPGEs to PPGEs (Figure 5), which are different from that the mantle wedge xenoliths from Kamchatka [27] but very similar to to the PGE patterns shown by the Stillerwater layered intrusions [3]. The total PGE contents of garnet peridotites range from $14.39 \mathrm{ppb}$ to $21.65 \mathrm{ppb}$. They have high $\mathrm{Pd} / \mathrm{Ir}$ ratios up to 10 that are remarkably higher than that of the primitive mantle. It has been suggested that the typical mantle xenoliths and Alpinetype orogenic peridotites have flat PGE patterns, in which the PGEs are not fractionated [3]. Furthermore, partial melting would lead to depletion of PPGEs over IPGEs in the mantle residues, which should display flat to negative PGE patterns [3, 22, 28, 29]. Therefore, we suggest that the Bixiling garnet peridotites are refractory mantle residues after melt extraction but represent fractional crystallization products of mantle-derived melts, which is also supported by both trace-element and isotope compositions as discussed above.

The PGE patterns of both nattier blue eclogites and greenish black eclogites are distinguished from each other due to their very low contents of $\mathrm{Ir}$ and $\mathrm{Ru}$, which are even lower than their detection limits. The Bixiling eclogites have low total contents of PGEs, which range from $0.25 \mathrm{ppb}$ to $0.96 \mathrm{ppb}$. They display fractionated PGE patterns, which increase from IPGEs to PPGEs. This implies that they represent the late-stage products of magmatic differentiation. The PGE patterns of the Bixiling mafic-ultramafic rocks vary with the lithologies. The PGE content systematically decreases from the garnet peridotites to the eclogites, which show positive correlations with the $\mathrm{MgO}$ contents. Along with the magmatic differentiation, variations in PPGEs (i.e., $\mathrm{Pt}$ and $\mathrm{Pd}$ ) are more limited than those observed for IPGEs (i.e., Ir and Ru). This suggests that the IPGEs are compatible during fractional crystallization and controlled by phases (e.g., metal alloys, chromite, olivine, or clinopyroxene) other than low-temperature sulphides [7].

\section{Discussion}

Although it has been suggested that the PGEs can be mobilized and fractionated by secondary post-magmatic events, such as hydrothermal alteration or weathering [30], it has been widely accepted that the PGEs are immobile under near-surface conditions. For example, Rehkämper et al. [31] suggested that the PGE budgets of abyssal peridotites have not been significantly disturbed by low-temperature alteration $\left(<150^{\circ} \mathrm{C}\right)$. Furthermore, it has also been suggested that the PGEs are immobile during serpentinization $\left(<600^{\circ} \mathrm{C}\right)$ processes, for which is commonly taken place under very reducing conditions [31, 32]. Büchl et al. [33] demonstrated that the PGEs are also significantly fractionated by hydrothermal fluids. Therefore, the fractionated PGE patterns observed in the Raobazhai peridotites cannot be ascribed to any secondary process; their PGE patterns reflect the magmatic processes occurred in the mantle, such as partial melting and melt percolation. The Raobazhai peridotites display enrichment in IPGEs over PPGEs, which is in stark contrast to the predicated PGE patterns of residual mantle peridotites. Hence, we believe that their PGE budgets have been affected by other processes than partial melting. 
Recently, various studies have shown that the PGE budgets of mantle peridotites could be significantly disturbed by metasomatic processes, including melt/fluid infiltration and percolation [34-40]. Unlike hydrous fluids, slab-derived melts are capable of carrying HFSE (e.g., $\mathrm{Zr}, \mathrm{Hf}, \mathrm{Nb}$ and $\mathrm{Ta})$ at some instances [41-43]. The mantle wedge could achieve such distinct geochemical signatures through extensive interaction with slab-derived melts [27]. It has also been suggested that slab-derived melts could fractionate the IPGEs from the PPGEs [27]. The positive relationship between $\mathrm{Pt} / \mathrm{Pd}$ ratio and Hf concentration shown by the Raobazhai mafic-ultramafic rocks indicates that they have been metasomatized by slab-derived melts. Occurrence of hydrous mineral in Raobazhai mafic-ultramafic rocks also supports that they have been interacted with hydrous melts during subduction and/or exhumation [44]. Segregation of secondary sulfides from the volatile-rich melts into the mantle peridotites could increase their Pd abundances [34]. Enrichment of PPGEs over IPGEs in the Raobazhai peridotites could be interpreted by addition of secondary sulfides. In conclusion, both PGE and trace-elements data suggest that the Raobazhai mafic-ultramafic rocks have been metasomatized by slab-derived melts.

The partition coefficient of $\mathrm{Cu}$ between sulfide and silicate melts $\left(\mathrm{D}^{\text {sulfide/silicate }}\right)$ has been experimentally determined to be $900-1400$, which is $3000-90000$ for Pd [45]. The covariation between $\mathrm{Cu}$ and $\mathrm{Pd}$ is a useful indicator for sulphide fractionation. Because $\mathrm{Cu}$ is much less chalcophile than $\mathrm{Pd}$, the $\mathrm{Cu} / \mathrm{Pd}$ ratio should increase if sulphide is fractionated from a magma. In the Bixiling garnet peridotites and eclogites, The $\mathrm{Cu} / \mathrm{Pd}$ ratio of the Bixiling garnet peridotites varies from $10^{3}$ to $10^{4}$, whereas it ranges from $10^{5}$ to $10^{7}$ for the Bixiling eclogites. As shown in the $\mathrm{Cu} / \mathrm{Pd}$ versus Pd diagram (Figure 6), the $\mathrm{Cu} / \mathrm{Pd}$ ratios of the garnet peridotites are close to the mantle values, which suggests that they have not experienced sulphide segregation prior to their emplacement [12]. If sulfide segregation had occurred in the Bixiling garnet peridotites, then their $\mathrm{Cu} / \mathrm{Pd}$ ratios should be greater than the normal mantle values because $\mathrm{Pd}$ is preferentially partitioning into sulfide liquid relative to $\mathrm{Cu}$. The PGE patterns of the Bixiling eclogites are consistent with sulfide segregation from these samples. That is, the $\mathrm{Cu} / \mathrm{Pd}$ ratio becomes elevated along with the increase of fractional crystallization.

Sulfide segregation is an inevitable process during fractional crystallization [7]. Fractional crystallization tend to decrease the $\mathrm{FeO}$ content in the residual magma, which might result in S saturation and thus formation of immiscible sulfide liquids [46]. The Bixiling garnet peridotites and eclogites were formed along with fractional crystallization, during which the $\mathrm{S}$ contents of the magmas became saturated to segregate sulfides. Removal of sulfides would lead to depletion of $\mathrm{Pd}$ in the residual magmas and increase in $\mathrm{Cu} / \mathrm{Pd}$ ratio (Figure 6).

The Bixiling mafic-ultramafic rocks display a positive correlation between $\mathrm{Ru}$ and $\mathrm{Pd}$, indicating that both elements are partitioning into the same kind of sulfides. The PGE data of the Bixiling mafic-ultramafic rocks suggest that

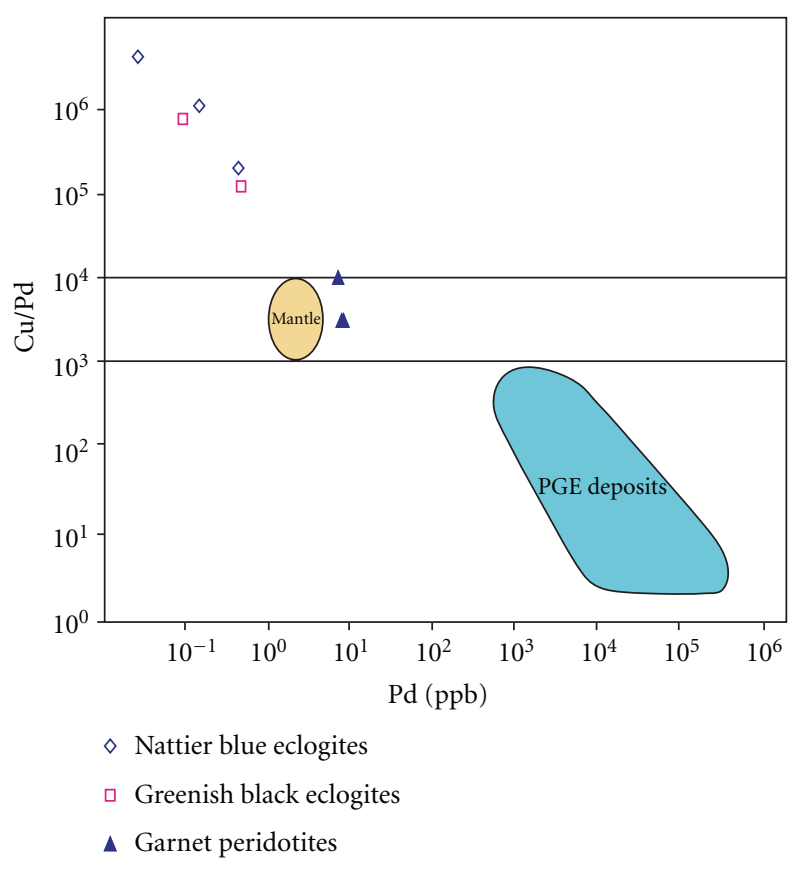

Figure 6: Plots of $\mathrm{Cu} / \mathrm{Pd}$ ratios versus $\mathrm{Pd}$ for Bixiling maficultramafic rocks (filled fields are after [12]).

the PGEs can be fractionated during magma differentiation. Both Ir and $\mathrm{Ru}$ are compatible in a nonsulfide phase, in which Pd is incompatible. Both petrological and geochemical studies have suggested that olivine $[47,48]$, spinel or chromite $[49,50]$, and refractory alloys $[51,52]$ are the most likely candidates [7]. However, modeling calculations have shown that neither olivine nor clinopyroxene can significantly fractionate the PGEs [7]. It has been suggested that the PGEs are not incorporated into the lattice of chromites but concentrated within tiny inclusions, such as sulfides or alloys. Therefore, chromites themselves are not able to fractionate the PGEs [52]. Keays [2] has suggested that both Ir and Os exist as Os-Ir alloys in the upper mantle. These tiny alloys can be physically segregated into the magmas during partial melting. They can be trapped within the crystallized silicate (e.g., olivine) and oxide (e.g., chromite) minerals, which results in the fractionation of the IPGEs from the PPGEs. Tredoux et al. [53] has also suggested that the PGEs and other nonlithophile elements could be aggregated together as clusters in silicate magmas. Theoretically, the IPGEs (i.e., Os and Ir) are more likely to form clusters than the PPGE (i.e., Rh and Pd) [53]. Therefore, we explain the enrichment of IPGEs rather than PPGEs in the Bixiling mafic-ultramafic rocks as entrainment of such clusters in these samples. The PGE alloys have been rarely reported in mantle peridotites, which could be due to their extremely small sizes. Microinclusions of Os, Ir, and Pt have been identified in Merensky sulfides, which support the occurrence of PGEs as polymetallic clusters in silicates [54]. However, future studies are still needed to investigate the PGE-rich phases in the mantle. 


\section{Conclusions}

On the basis of the geochemical compositions of both Raobazhai and Bixiling mafic-ultramafic rocks, in particular PGE data, we can draw the following primary conclusions:

(1) The Raobazhai mafic-ultramafic rocks show consistent PGE patterns, in which the PPGEs (e.g., Pt and Pd) are strongly enriched over the IPGEs (e.g., Ir and $\mathrm{Ru}$ ). Such patterns are in stark contrast to those displayed by refractory mantle residues after melt extraction, in which the IPGEs are enriched over the PPGEs. This indicates that the PGE budgets of the Raobazhai mafic-ultramafic rocks have been affected by processes other than partial melting. Both REE and PGE data support that the Raobazhai maficultramafic rocks have interacted with slab-derived melts during subduction and/or exhumation.

(2) The Bixiling mafic-ultramafic rocks were formed through fractional crystallization and cumulation from magmas. The PGE patterns shown by the Bixiling mafic-ultramafic rocks were produced by the magmatic differentiation processes, during which fractional crystallization of silicate minerals and segregation of immiscible sulfide liquids are involved. The fractionated PGE patterns of the Bixiling maficultramafic rocks reflect that $\mathrm{Pd}$ is incompatible in the nonsulfide phases, whereas both Ir and $\mathrm{Ru}$ are compatible in some mantle phases.

\section{Acknowledgments}

This research has been financially supported by the Nature Science Foundation of China (Grant no. 40702009; 41030422). The authors thank Tianshan Gao and Hongyuan Zhang for help in the field work, $\mathrm{He} \mathrm{Li}$ and Xindi Jin for major and trace element analyses, and Caifen $\mathrm{Nu}$ and Hongliao He for their help in PGE analyses. Comments from two reviewers greatly improved the quality of this paper.

\section{References}

[1] S. J. Barnes, R. Boyd, and A. Korneliussen, "The use of mantle normalization and metal ratios in discriminating between the effects of partial melting, crystal fractionation and sulphide segregation on platinum-group elements, gold, nickel and copper: examples from Norway," in Proceedings of the GeoPlatinum Conference, H. M. Prichard, J. W. Bowles, and P. Potts, Eds., pp. 113-143, Elsevier, Amsterdam, The Netherlands, 1988.

[2] R. R. Keays, "The role of komatiitic and picritic magmatism and S-saturation in the formation of ore deposits," Lithos, vol. 34, no. 1-3, pp. 1-18, 1995.

[3] S. J. Barnes, A. J. Naldrett, and M. P. Gorton, "The origin of the fractionation of platinum-group elements in terrestrial magmas," Chemical Geology, vol. 53, no. 3-4, pp. 303-323, 1985.

[4] J. P. Lorand, "Abundance and distribution of CuFeNi sulfides, sulfur, copper and platinum-group elements in orogenic-type spinel lherzolite massifs of Ariège (Northeastern Pyrenees,
France)," Earth and Planetary Science Letters, vol. 93, no. 1, pp. 50-64, 1989.

[5] G. Garuti, C. Gorgoni, and G. P. Sighinolfi, "Sulfide mineralogy and chalcophile and siderophile element abundances in the Ivrea-Verbano mantle peridotites (Western Italian Alps)," Earth and Planetary Science Letters, vol. 70, no. 1, pp. 69-87, 1984.

[6] G. Garuti, G. Fershtater, F. Bea, P. Montero, E. V. Pushkarev, and F. Zaccarini, "Platinum-group elements as petrological indicators in mafic-ultramafic complexes of the central and southern Urals: preliminary results," Tectonophysics, vol. 276, no. 1-4, pp. 181-194, 1997.

[7] M. Rehkämper, A. N. Halliday, J. G. Fitton, D. C. Lee, M. Wieneke, and N. T. Arndt, "Ir, Ru, Pt, and Pd in basalts and komatiites: new constraints for the geochemical behavior of the platinum-group elements in the mantle," Geochimica et Cosmochimica Acta, vol. 63, no. 22, pp. 3915-3934, 1999.

[8] B. M. Jahn, F. Wu, C. H. Lo, and C. H. Tsai, "Crust-mantle interaction induced by deep subduction of the continental crust: geochemical and Sr-Nd isotopic evidence from postcollisional mafic-ultramafic intrusions of the northern Dabie complex, central China," Chemical Geology, vol. 157, no. 1-2, pp. 119-146, 1999.

[9] S. S. Sun and W. F. McDonough, "Chemical and isotopic systematics of oceanic basalts: implications for mantle composition and processes," Magmatism in the Ocean Basins, pp. 313-345, 1989.

[10] B. R. Hacker, L. Ratschbacher, L. Webb et al., "Exhumation of ultrahigh-pressure continental crust in east central China: late Triassic-Early Jurassic tectonic unroofing," Journal of Geophysical Research B, vol. 105, no. 6, pp. 13339-13364, 2000.

[11] J. Zheng, M. Sun, M. F. Zhou, and P. Robinson, "Trace elemental and PGE geochemical constraints of Mesozoic and Cenozoic peridotitic xenoliths on lithospheric evolution of the North China Craton," Geochimica et Cosmochimica Acta, vol. 69, no. 13, pp. 3401-3418, 2005.

[12] S. J. Barnes and C. P. Picard, "The behaviour of platinumgroup elements during partial melting, crystal fractionation, and sulphide segregation: an example from the Cape Smith Fold Belt, northern Quebec," Geochimica et Cosmochimica Acta, vol. 57, no. 1, pp. 79-87, 1993.

[13] B. R. Hacker, L. Ratschbacher, L. Webb, T. Ireland, D. Walker, and $\mathrm{D}$. Shuwen, "U/Pb zircon ages constrain the architecture of the ultrahigh-pressure Qinling-Dabie Orogen, China," Earth and Planetary Science Letters, vol. 161, no. 1-4, pp. 215230, 1998.

[14] X. Yang, "A cold ultramafic intrusive body in Dabieshan area, Anhui Province," Bulletin of Nanjing Institute of Geology, vol. 4, pp. 81-95, 1983.

[15] S. Xu, L. Jiang, Y. Liu, and Y. Zhang, "Tectonic framework and evolution of the Dabie Mountains in Anhui, eastern China," Acta Geologica Sinica, vol. 5, pp. 221-238, 1992.

[16] C. H. Tsai, J. C. Liou, and W. G. Ernst, "Petrological characterization and tectonic significance of retrogressed garnet peridotites, Raobazhai area, North Dabie Complex, eastcentral China," Journal of Metamorphic Geology, vol. 18, no. 2, pp. 181-192, 2000.

[17] Q. Zhang, B. Ma, R. Liu et al., "A remnant of continental lithospheric mantle above subduction zone: geochemical constraints on ultramafic rock from Raobazhai area, Anhui province," Science in China Series B, vol. 38, no. 12, pp. 15221529, 1995.

[18] X. C. Zhi, Y. B. Jin, Q. Meng, and T. S. Gao, “Trace element geochemistry of Raobazhai ultramafic complex, North Dabie 
Mountain," Acta Petrologica Sinica, vol. 20, no. 3, pp. 463-472, 2004.

[19] R. Y. Zhang, J. G. Liou, and B. L. Cong, "Ultrahigh-pressure metamorphosed talc-, magnesite- and Ti-clinohumite-bearing mafic-ultramafic complex, Dabie mountains, east-central China," Journal of Petrology, vol. 36, no. 4, pp. 1011-1037, 1995.

[20] V. Chavagnac and B. M. Jahn, "Coesite-bearing eclogites from the Bixiling Complex, Dabie Mountains, China: Sm-Nd ages, geochemical characteristics and tectonic implications," Chemical Geology, vol. 133, no. 1-4, pp. 29-51, 1996.

[21] H. Downes, "Formation and modification of the shallow sub-continental lithospheric mantle: a review of geochemical evidence from ultramatic xenolith suites and tectonically emplaced ultramafic massifs of Western and Central Europe," Journal of Petrology, vol. 42, no. 1, pp. 233-250, 2001.

[22] K. Gueddari, M. Piboule, and J. Amossé, "Differentiation of platinum-group elements (PGE) and of gold during partial melting of peridotites in the lherzolitic massifs of the BeticoRifean range (Ronda and Beni Bousera)," Chemical Geology, vol. 134, no. 1-3, pp. 181-197, 1996.

[23] J. W. Morgan, "Ultramafic xenoliths: clue to the earth's late accretionary history," Journal of Geophysical Research, vol. 91, pp. 12375-12387, 1986.

[24] J. P. Lorand, L. Pattou, and M. Gros, "Fractionation of Platinum-group elements and gold in the upper mantle: a detailed study in Pyrenean orogenic lherzolites," Journal of Petrology, vol. 40, no. 6, pp. 957-981, 1999.

[25] W. F. McDonough and F. A. Frey, "Rare earth elements in upper mantle rocks," in Geochemistry and Mineralogy of the Rare Earth Elements, B. R. Lipin and G. A. McKay, Eds., vol. 21, pp. 99-145, Mineralogical Society of America, 1989.

[26] R. Y. Zhang, D. Rumble, J. G. Liou, and Q. C. Wang, "Low $\delta^{18} \mathrm{O}$, ultrahigh-P garnet-bearing mafic and ultramafic rocks from Dabie Shan, China," Chemical Geology, vol. 150, no. 1-2, pp. 161-170, 1998.

[27] P. Kepezhinskas, M. J. Defant, and E. Widom, "Abundance and distribution of PGE and $\mathrm{Au}$ in the island-arc mantle: implications for sub-arc metasomatism," Lithos, vol. 60, no. 3-4, pp. 113-128, 2002.

[28] G. E. Brügmann, N. T. Arndt, A. W. Hofmann, and H. J. Tobschall, "Noble metal abundances in komatiite suites from Alexo, Ontario and Gorgona Island, Colombia," Geochimica et Cosmochimica Acta, vol. 51, no. 8, pp. 2159-2169, 1987.

[29] J. P. Lorand, R. R. Keays, and J. L. Bodinier, "Copper and noble metal enrichments across the lithosphere-asthenosphere boundary of mantle diapirs: evidence from the lanzo lherzolite massif," Journal of Petrology, vol. 34, no. 6, pp. 1111-1140, 1993.

[30] J. J. Standish, S. R. Hart, J. Blusztajn, H. J. B. Dick, and K. L. Lee, Abyssal peridotite osmium isotopic composition for Crspinel, Geochem. Geophys. Geosyst. 2001GG000161, 2001.

[31] M. Rehkämper, A. N. Halliday, J. Alt, J. G. Fitton, J. Zipfel, and E. Takazawa, "Non-chondritic platinum-group element ratios in oceanic mantle lithosphere: petrogenetic signature of melt percolation?" Earth and Planetary Science Letters, vol. 172, no. 1-2, pp. 65-81, 1999.

[32] J. E. Snow and G. Schmidt, "Constraints on Earth accretion deduced from noble metals in the oceanic mantle," Nature, vol. 391, no. 6663, pp. 166-169, 1998.

[33] A. Büchl, G. Brügmann, V. G. Batanova, C. Münker, and A. W. Hofmann, "Melt percolation monitored by Os isotopes and HSE abundances: a case study from the mantle section of the
Troodos Ophiolite," Earth and Planetary Science Letters, vol. 204, no. 3-4, pp. 385-402, 2002.

[34] J. P. Lorand, L. Reisberg, and R. M. Bedini, "Platinum-group elements and melt percolation processes in Sidamo spinel peridotite xenoliths, Ethiopia, East African Rift," Chemical Geology, vol. 196, no. 1-4, pp. 57-75, 2003.

[35] J. P. Lorand, G. Delpech, M. Grégoire, B. Moine, S. Y. O’Reilly, and J. Y. Cottin, "Platinum-group elements and the multistage metasomatic history of Kerguelen lithospheric mantle (South Indian Ocean)," Chemical Geology, vol. 208, no. 1-4, pp. 195215, 2004.

[36] J. P. Lorand, A. Luguet, O. Alard, A. Bezos, and T. Meisel, "Abundance and distribution of platinum-group elements in orogenic lherzolites; a case study in a Fontete Rouge lherzolite (French Pyrénées)," Chemical Geology, vol. 248, no. 3-4, pp. 174-194, 2008.

[37] L. Reisberg, X. Zhi, J. P. Lorand, C. Wagner, Z. Peng, and C. Zimmermann, "Re-Os and S systematics of spinel peridotite xenoliths from east central China: evidence for contrasting effects of melt percolation," Earth and Planetary Science Letters, vol. 239, no. 3-4, pp. 286-308, 2005.

[38] H. Becker, M. F. Horan, R. J. Walker, S. Gao, J. P. Lorand, and R. L. Rudnick, "Highly siderophile element composition of the Earth's primitive upper mantle: constraints from new data on peridotite massifs and xenoliths," Geochimica et Cosmochimica Acta, vol. 70, no. 17, pp. 4528-4550, 2006.

[39] L. Ackerman, R. J. Walker, I. S. Puchtel, L. Pitcher, E. Jelínek, and L. Strnad, "Effects of melt percolation on highly siderophile elements and Os isotopes in subcontinental lithospheric mantle: a study of the upper mantle profile beneath Central Europe," Geochimica et Cosmochimica Acta, vol. 73, no. 8, pp. 2400-2414, 2009.

[40] Y. Xiao and H.-F. Zhang, "Effects of melt percolation on platinum group elements and Re-Os systematics of peridotites from the Tan-Lu fault zone, eastern North China Craton," Journal of the Geological Society, vol. 168, no. 5, pp. 1201-1214, 2011.

[41] M. J. Defant and M. S. Drummond, "Derivation of some modern arc magmas by melting of young subducted lithosphere," Nature, vol. 347, no. 6294, pp. 662-665, 1990.

[42] M. S. Drummond, M. J. Defant, and P. K. Kepezhinskas, "Petrogenesis of slab-derived trondhjemite-tonalite-dacite/adakite magmas," Transactions of the Royal Society of Edinburgh, Earth Sciences, vol. 87, no. 1-2, pp. 205-215, 1996.

[43] H. Martin, "Adakitic magmas: modern analogues of Archaean granitoids," Lithos, vol. 46, no. 3, pp. 411-429, 1999.

[44] L. Zheng, X. Zhi, and L. Reisberg, "Re-Os systematics of the Raobazhai peridotite massifs from the Dabie orogenic zone, eastern China," Chemical Geology, vol. 268, no. 1-2, pp. 1-14, 2009.

[45] S.-J. Barnes and W. D. Maier, "The fractionation of Ni, Cu, and the noble metals in silicate and sulphide liquids," in Dynamic Processes in Magmatic Ore Deposits and Their Application in Mineral Exploration, R. R. Keays, Ed., Short Course Notes 13, pp. 69-106, Geological Association Canada, 1999.

[46] W. Yi, A. N. Halliday, J. C. Alt et al., "Cadmium, indium, tin, tellurium, and sulfur in oceanic basalts: implications for chalcophile element fractionation in the Earth," Journal of Geophysical Research B, vol. 105, no. 8, pp. 18927-18948, 2000.

[47] G. E. Brügmann, N. T. Arndt, A. W. Hofmann, and H. J. Tobschall, "Noble metal abundances in komatiite suites from Alexo, Ontario and Gorgona Island, Colombia," Geochimica et Cosmochimica Acta, vol. 51, no. 8, pp. 2159-2169, 1987. 
[48] M. F. Zhou, "PGE distribution in 2.7-Ga layered komatiite flows from the Belingwe greenstone belt, Zimbabwe," Chemical Geology, vol. 118, no. 1-4, pp. 155-172, 1994.

[49] I. O. Oshin and J. H. Crocket, "Noble metals in Thetford Mines ophiolites, Quebec, Canada-part I: distribution of gold, iridium, platinum, and palladium in the ultramafic and gabbroic rocks," Economic Geology, vol. 77, no. 6, pp. 1556-1570, 1982.

[50] C. J. Capobianco, R. L. Hervig, and M. J. Drake, "Experiments on crystal/liquid partitioning of $\mathrm{Ru}, \mathrm{Rh}$ and $\mathrm{Pd}$ for magnetite and hematite solid solutions crystallized from silicate melt," Chemical Geology, vol. 113, no. 1-2, pp. 23-43, 1994.

[51] C. Ballhaus, "Is the upper mantle metal-saturated?" Earth and Planetary Science Letters, vol. 132, no. 1-4, pp. 75-86, 1995.

[52] R. J. Walker, E. Hanski, J. Vuollo, and J. Liipo, "The Os isotopic composition of Proterozoic upper mantle: evidence for chondritic upper mantle from the Outokumpu ophiolite, Finland," Earth and Planetary Science Letters, vol. 141, no. 1-4, pp. 161-173, 1996.

[53] M. Tredoux, N. M. Lindsay, G. Davies, and I. McDonald, "The fractionation of platinum-group elements in magmatic systems, with the suggestion of a novel causal mechanism," South African Journal of Geology, vol. 98, no. 2, pp. 157-167, 1995.

[54] C. Ballhaus and P. Sylvester, "Spatial platinum-group-element distribution in magmatic sulfides: implications for the platinum group-element behavior during mantle melting," in Proceedings of the 7th Annual V.M. Goldschmidt Conference, pp. 15-16, 1997. 

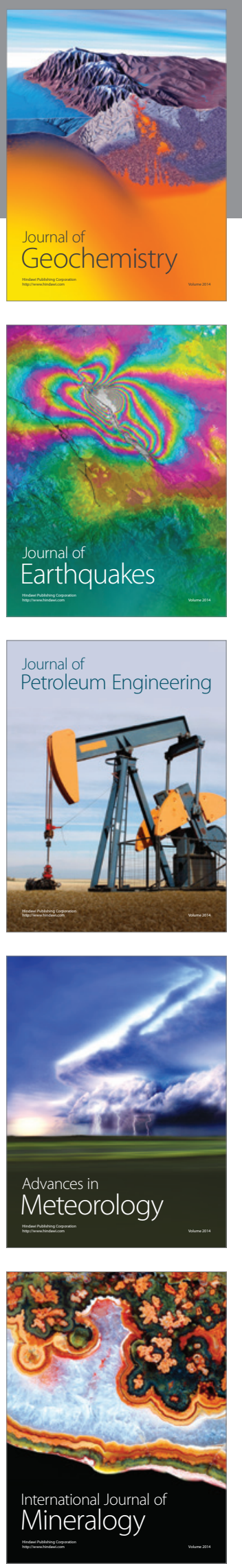
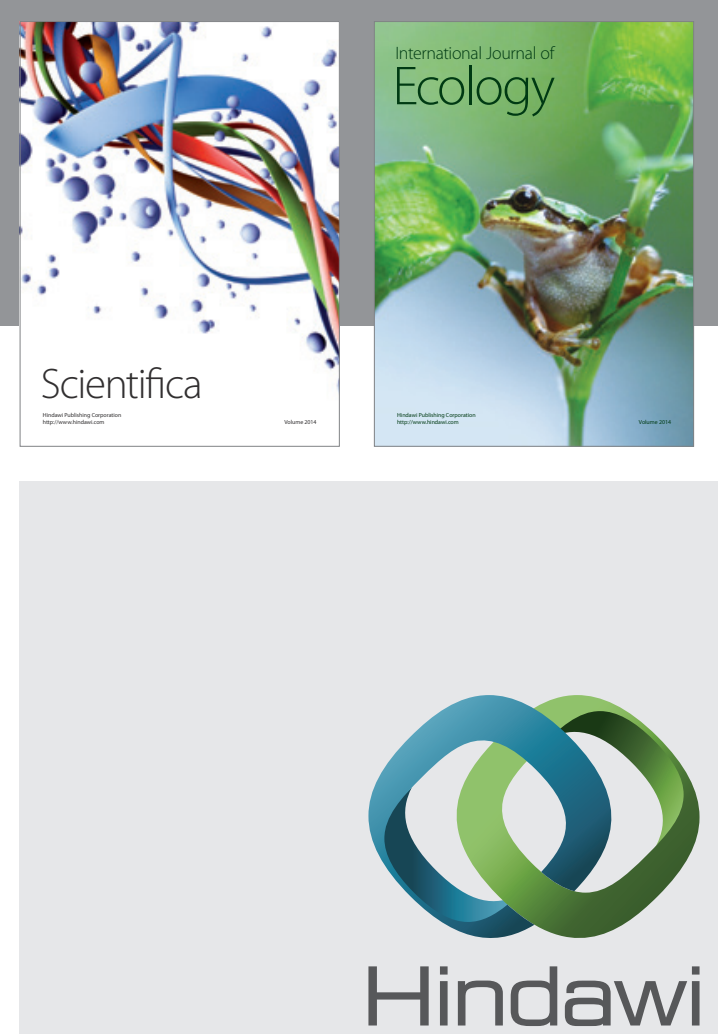

Submit your manuscripts at http://www.hindawi.com
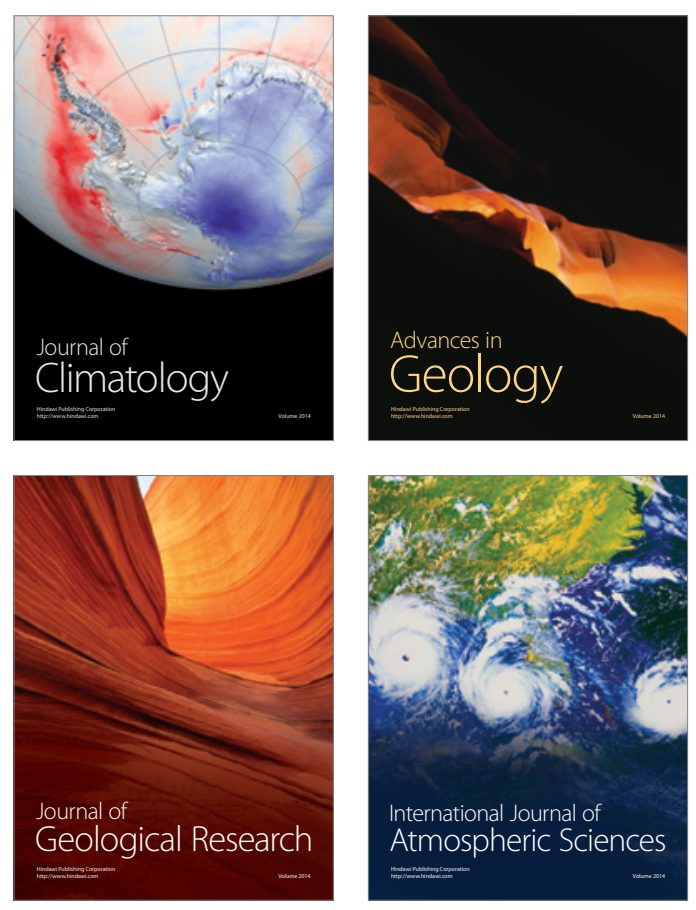
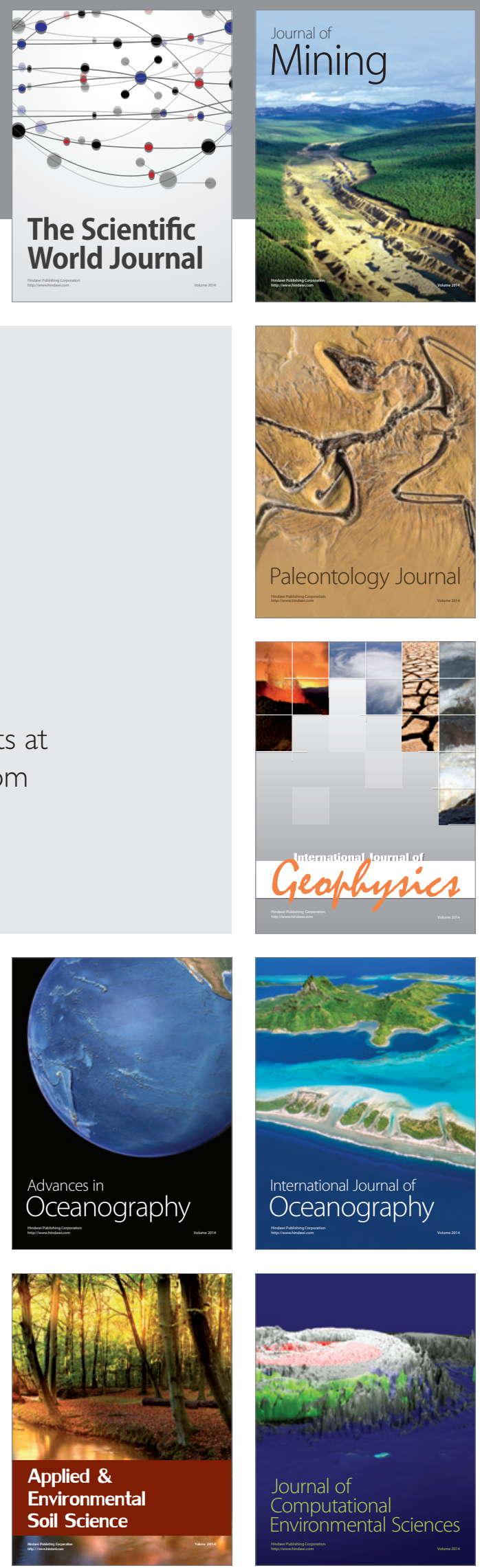